\title{
NEOLIBERALIZM, ORDOLIBERALIZM, AUSTRIACKA SZKOŁA EKONOMII A ŁAD GOSPODARCZY KAPITALIZMU
}

\author{
KONFERENCJA NAUKOWA \\ WYŻSZEJ SZKOŁY FINANSÓW I ZARZA¿ZZANIA W BIAŁYMSTOKU, \\ WYDZIAŁU EKONOMII I ZARZACDZANIA UNIWERSYTETU W BIAŁYMSTOKU \\ BIAŁYSTOK, 12-13 MARCA 2013 R.
}

W dniach 12 i 13 marca 2013 r. w gościnnych murach białostockich uczelni - Wyższej Szkoły Finansów i Zarządzania oraz Wydziału Ekonomii i Zarządzania Uniwersytetu w Białymstoku - odbyła się konferencja naukowa poświęcona myśli liberalnej i ładowi gospodarczemu. ${ }^{2}$ Spotkanie zainicjowali profesorowie Piotr Pysz i Robert Ciborowski, wzięli w nim udział przedstawiciele licznych ośrodków akademickich: krajowych i zagranicznych.

U podstaw organizacji konferencji legło słuszne - jak się okazało - założenie, że odpowiednia formuła i kameralny charakter umożliwią dobre forum gorących dyskusji i wymiany poglądów. Prelegenci z odpowiednim wyprzedzeniem przygotowali swoje wystapienia i udostępnili je innym uczestnikom, dzięki czemu w trakcie prelekcji była możliwa koncentracja na najważniejszych tezach. Dodatkowo uczestnicy przygotowywali wzajemnie komentarze do swoich artykułów, co zachęcało do pogłębionej lektury i wnikliwych uwag.

Konferencję podzielono na kilka bloków tematycznych, obejmujących teorię ładu gospodarczego, następnie zagadnienia ładu w procesie transformacji systemowej i wreszcie - problemy polityki gospodarczej w ramach ładu gospodarki kapitalistycznej.

Otwierające obrady wystapienie profesor Elżbieta Mączyńska, Prezes Polskiego Towarzystwa Ekonomicznego, profesor SGH, poświęciła „Ordoliberalizmowi i wyzwaniom współczesności”. Tok wywodów opierał się na tezie, iż (...) dysfunkcje w gospodarce globalnej i niepowodzenia $w$ przeciwdziałaniu im mają pierwotne podłoże przede wszystkim w niedostosowaniu praktyki i polityki gospodarczej oraz polityki ustroju społeczno-gospodarczej do wyzwań wynikających z dokonującego się obecnie w skali globalnej przełomu cywilizacyjnego, wyrażającego się w wypieraniu cywilizacji przemysłowej przez nową gospodarkę i nowy, wciąż jeszcze nie dodefiniowany jej nowy model. Wnikliwe rozważania o dysfunkcjach współczesnej gospodarki, przy równoległym wskazaniu na ahistoryczność podejścia neoliberalnego, pozwoliły wyprowadzić wniosek o konieczności poszukiwań nowych niekonwencjonalnych wzorców i teoretycznych podstaw dokonywania wyborów ekonomicznych. W dalszej kolejności prelegentka zestawiła liberalizm klasyczny z neoliberalizmem i ordoliberalizmem, co zakreśliło pole badawcze dwudniowym obradom. Profesor Mączyńska zaakcentowała negatywne zjawiska łamania obietnic w życiu społeczno-gospodarczym, erozji zaufania, którym sprzyjaja dysfunkcje prawa $\mathrm{i}$ - w opozycji do neoliberalizmu - skierowała uwagę na zalety ordoliberalizmu jako teoretycznej podstawy kształtowania nowych wzorców instytucjonalno-ustrojowych.

\footnotetext{
${ }^{1}$ Dr Michał Moszyński - Uniwersytet Mikołaja Kopernika w Toruniu, e-mail: moszyn@umk.pl.

${ }^{2}$ Konferencja odbyła się w ramach projektu badawczego nr N N 112258439 „Koncepcje stanowionego i spontanicznego ładu gospodarczego w procesie transformacji systemowej gospodarki Polski i byłej NRD“, finansowanego ze środków Ministerstwa Nauki i Szkolnictwa Wyższego”.
} 
Komentując wystapienie profesor Mączyńskiej, doktor Justyna Schulz z Uniwersytetu w Bremie podkreśliła kluczowe znaczenie zaufania do funkcjonowania systemu ekonomicznego bazującego na umowach monetarnych, zawieranych pomiędzy obcymi osobami, oddalonymi w przestrzeni, z terminami zapadalności odległymi w czasie. Brak zaufania wiaże się z redukcja transakcji ekonomicznych. Autorka zwróciła uwagę na fakt, że zilustrowana przez profesor Mączyńska, na przykładzie afery Amber Gold, forma łamania obietnic stanowi zaprzeczenie jednego z podstawowych postulatów ordoliberalizmu, jakim jest zależność pomiędzy podejmowanym ryzykiem a ponoszoną odpowiedzialnością majątkową. Na zakończenie komentarza autorka zaproponowała, aby tzw. „dylemat Böckenförda”, zakładający, że dla funkcjonowania demokratycznego państwa są nieodzowne wartości etyczno-moralne, których generowanie państwo nie jest w stanie zagwarantować, również rozszerzyć na system ekonomiczny.

Rozważania na płaszczyźnie stricte teoretycznej były kontynuowane w referacie profesor Anny Ząbkowicz z INE PAN i Uniwersytetu Jagiellońskiego. Autorka zastanawiała się nad transformacją ładu instytucjonalnego i samoregulującej się gospodarki z perspektywy Waltera Euckena i Karla Polanyi'ego. Porównanie koncepcji obu myślicieli orientowało się wokół interesującego spostrzeżenia, iż koncept samoregulującego się rynku stanowi dla nich punkt odniesienia, lecz jest odmiennie rozumiany i wartościowany. U Euckena czytamy o transformacji DO wzorcowej, samoregulującej się gospodarki rynkowej, podczas gdy Polanyi mówi o transformacji OD: instytucji rynku pracy, ziemi i pieniądza. Eucken określa warunki, które umożliwią przejście do wzorcowego ładu opartego na konkurencji, natomiast Polanyi analizuje klęskę samoregulującego się rynku. Profesor Ząbkowicz przekonująco wykazała, że wciąż warto wracać do żywotnej idei samoregulującego się rynku, zwłaszcza że współcześnie globalizująca się gospodarka wzmacnia pewne cechy charakterystyczne dla leseferyzmu. Podsumowując, stwierdziła, że na przeszkodzie w realizacji wizji Euckena i Polanyi'ego stoi kwestia realizacji aktywnej polityki, która pozostaje nierozstrzygnięta. Eucken wątpi w skuteczny nadzór nad monopolami przez nowoczesne państwo, z kolei u Polanyi'ego problem władzy nie dotyczy państwa ani siły grup nacisku, ale „władzy nad umysłami”. Te rozważania, jak wskazuje profesor Ząbkowicz, nie powinny pójść w zapomnienie, szczególnie, że koncepcja samoregulującego się rynku jest nadal atrakcyjna dla współczesnych uczestników życia społeczno-gospodarczego.

Odpowiadając na kwestię władzy w nowoczesnym państwie, profesor Piotr Pysz z Wyższej Szkoły Finansów i Zarządzania w Białymstoku stwierdził, że: państwo powinno umieć się ograniczać, gdyż straci władzę nad wszystkim. Powinno zatem kształtować ład, a resztę zostawić rynkowi. Pytanie brzmi, jak uwolnić rząd od zajmowania się sprawami nieistotnymi. Profesor przytoczył tezę W. Röpke, iż rynek zużywa substancję, której sam nie wytwarza, w nawiązaniu do rozprzestrzeniającego się myślenia w kategoriach gier niekooperacyjnych i niebezpieczeństwa przekształcenia się gospodarki rynkowej w społeczeństwo rynkowe.

Profesor Pysz poświęcił swoje wystapienie analizie porównawczej koncepcji ładu gospodarczego Waltera Euckena i Friedricha Augusta von Hayeka. Wychodząc od Hayekowskiej tezy o narastającej złożoności współczesnego świata, prelegent zapytał o rolę nauki i polityki wobec tego zjawiska. Porównując programy badawcze Euckena i Hayeka, uznał, iż ich stanowiska nie wykluczają się, a poglądy tworzą ogólną teorię ładu gospodarczego, choć u Hayeka strona etyczna jest mniej widoczna niż u Euckena. Gospodarka obu badaczy interesowała jako źródło refleksji teoretycznej, lecz warto pamiętać, że zarówno oni, jak i Erhard, Röpke i inni początkowo zajmowali się bieżącymi problemami gospodarki.

Profesor Maciej Miszewski zauważył, że słabym punktem w Euckenowskiej analizie jest nierozwiazzanie kwestii, jak stworzyć to modelowe państwo. Z kolei, profesor Witold Kwaśnicki, odnosząc się do problemu zaufania, zaoponował przeciw poglądowi o spadającej kooperacji międzyludzkiej, przytaczając przykłady spontanicznej współpracy społecznej w USA. Dodał, iż zbyt mocno krytykuje się rynek, który nie jest przecież jedyną formą życia społecznego. Przestrzegł także przed dodawaniem do rzeczowników przymiotników, które zmieniaja ich sens, jak ma to miejsce w przypadku zbitek, takich jak: „wolny rynek”, „społeczna gospo- 
darka” itp. Profesor Godłów-Legiędź podkreśliła normatywny charakter ładu spontanicznego w sensie postulatu poszanowania tego, co doświadczenie i historia wniosły do organizacji życia społecznego. Nie negując potrzeby stanowienia ładu, uznała, że należy opierać go na sprawdzonych rozwiązaniach. Natomiast profesor Ząbkowicz zwróciła uwagę na postulatywny charakter koncepcji Hayeka, która głosi: „Pozwólmy gospodarce rozwijać się!”.

Kolejna prelekcja, która przygotowała profesor Janina Godłów-Legiędź z Uniwersytetu Łódzkiego, dotyczyła ideologii liberalnej i keynesowskiej widzianej z perspektywy globalnego kryzysu. Autorka świadomie użyła terminu „ideologia”, a nie „teoria” lub „ekonomia” i na tym rozróżnieniu oparła swoje początkowe wywody. Pomimo wyparcia z ekonomii głównego nurtu rozważań o charakterze ideologicznym na rzecz prób tworzenia czystej teorii i twardej nauki, ideologie wciąż pozostaja, przekonywała profesor, ważnym przedmiotem uwagi ekonomisty. $Z$ jednej bowiem strony kształtują przekonania i leżą u podstaw tworzenia i ewolucji instytucji, a z drugiej - systemy poglądów ekonomicznych przyjmuja postać ideologii. Zdaniem prelegentki, w ideologiach liberalnej i keynesowskiej występuje pewne twarde jądro ekonomii pozytywnej, obudowane trudnymi do rozgraniczenia elementami normatywnymi, które $z$ kolei wpływają na percepcję świata i proces poznawczy. To, że nasza wiedza jest niepełna i skażona heurystykami poznawczymi uzmysławia dorobek psychologii kognitywnej, coraz modniejszej również i w naukach ekonomicznych. Ideologia w ekonomii przejawia się między innymi w metodologii - koncentracji na stronie formalistycznej i matematycznej analizie modelowej. Profesor Godłów-Legiędź, podsumowując rozważania o ideologicznych podstawach polityki, zauważyła, że losy idei bywaja zadziwiające, a ich twórcy - jak Keynes i Smith - nie maja bo przecież mieć już nie moga, wpływu na ich dalszy rozwój i aplikację w zupełnie odmiennych warunkach. Wykorzystywanie retoryki liberalnej i keynesowskiej nie zmienia faktu, że politykę kształtuje się jedynie pod naciskiem sytuacji i wypadkowej sprzecznych sił grup interesu.

W koreferacie profesor Józefa Famielec z Uniwersytetu Ekonomicznego w Krakowie uznała, że w analizie konkretnych zjawisk, jak choćby kryzysu, nie powinno się w prosty sposób uznawać racji lub podważać określonej ideologii. Ekonomia staje bowiem przed wieloma zadaniami, w tym przed wyjaśnieniem transformacji gospodarki rynkowej. Do wyjaśnienia, tak złożonych zagadnień, mogą być przydatne - zdaniem profesor Famielec - zarówno ideologie liberalne, jak i keynesowskie. Można je wykorzystać do ponownego zdefiniowania celów rozwoju gospodarczego w krótkiej i długiej perspektywie.

Doktor Wojciech Giza z Uniwersytetu Ekonomicznego w Krakowie zauważył, że należy odróżnić Keynesa od keynesistów, a bogactwo myśli Keynesa obejmuje inspiracje kolejnych pokoleń ekonomistów. Przypomniał, że postulat stymulowania koniunktury pochodzi od ucznia Keynesa, Abby Lernera, i zadał retoryczne pytanie: „Która interpretacja Keynesa jest prawdziwa?". Dodał, że na świat patrzymy przez pryzmat tego, co czytamy i widzimy, dlatego przykładowo odmienne poglądy Hayeka i Keynesa na pieniądz wynikały z różnych doświadczeń (inflacji, przewartościowania funta itp.). Profesor Witold Kwaśnicki z Uniwersytetu Wrocławskiego stwierdził, że Keynes dopuścił tak różnorodne interpretacje, stąd „Ogólna teoria...” została napisana chaotycznie, a sam często zmieniał poglądy.

Profesor Kazimierz Meredyk z Uniwersytetu w Białymstoku, w kolejnym referacie, przedstawił koncepcje tzw. wielkiej kwadrygi postępu oraz potrójnej helisy H. Etzkovitza, które stanowiły pretekst do rozważań nad formowaniem się ładu gospodarczego w Polsce po $1993 \mathrm{r}$.

Profesor Sergey Łukin z Uniwersytetu w Mińsku zaprezentował referat pt. „Chrześcijański punkt widzenia na ekonomiczny liberalizm”. Przyjrzał się w nim instytucjom życia gospodarczego w zapisach biblijnych oraz poglądom Kościoła Katolickiego na liberalizm ekonomiczny. Przytoczone przykłady ukazały zależność wartości mienia od prawa popytu i podaży. Działanie mechanizmu rynkowego pokazano w warunkach: pokoju, wojny, kataklizmów i urodzaju. Wykazano, że prawa ekonomiczne kształtowały się więc w sposób naturalny, niezależnie od woli człowieka. Rozważania te stały się przyczynkiem do drugiej części opracowania analizy współczesnych nauk społecznych: katolickiej nauki społecznej w relacji do marksizmu i liberalizmu. Autor starał się następnie wykazać, iż trzecia droga - proponowana przez Kościół - w znacznej mierze zbiega się z postulatami szkoły ordoliberalnej. 
Doktor Michał Moszyński z Uniwersytetu Mikołaja Kopernika w Toruniu, komentując artykuł uznał, że jego lektura rodzi refleksje o nie wykorzystanej wiedzy Kościoła. Znajomość, przynajmniej najważniejszych, postulatów zawartych w ostatnich encyklikach dowodzi, że Kościół podejmuje ważkie problemy gospodarcze, wokół których koncentruje się uwaga społeczeństw i ekonomistów. Jednakże w ogólnej świadomości nie są one obecne. Dorobek wielu myślicieli katolickich, zdolnych objąć złożoność rzeczywistości, składa się na spójną propozycję normatywnej ekonomiki. W Polsce Kościół jest postrzegany przez pryzmat: wiary, polityki i utartych opinii. Jednocześnie sam Kościół chyba zbyt mało wagi przykłada do głoszenia swych nauk społecznych, skupiając się na innych sferach życia.

Doktor Wojciech Giza zaprezentował referat pt. „Ład gospodarczy a teoria gier”, w którym rozwinął koncepcje Smithowskiej, niewidzialnej ręki w modele równowagi Pareto i Nasha. $\mathrm{Na}$ przykładzie gry „dylemat więźnia” próbował oddać grę rynkową i zapytać, czy cechy najlepszego algorytmu rozwiązującego ten dylemat, czyli: „przyjazność”, „odwetowość”, „skłonność do przebaczania” i „spójność” dobrze oddają naturę człowieka i jego zachowania na rynku. Prelegent analizował motywy działania jednostek oraz ich społeczne konsekwencje, wychodząc od przypomnienia liberalnych założeń, iż nawet motywacja oparta na własnej korzyści przynosi korzyści ogólnospołeczne. W refleksji nad adekwatnością gry "dylemat więźnia" w stosunku do mechanizmu rynkowego skupił się na kwestii powtarzalności wymiany (gry), by przejść do zachowań kooperacyjnych uczestników rynku (graczy). Doktor Giza przytoczył myśl Euckena, że we współczesnych, zcentralizowanych systemach społeczno-gospodarczych najczęściej mamy do czynienia nie ze spontanicznym porządkiem, ale z planem zakładającym określoną wizję ładu społeczno-gospodarczego. To spostrzeżenie nabiera innego znaczenia, gdy zwrócimy uwagę na rosnący stopień komplikacji relacji interpersonalnych we współczesnym świecie. Wraz z rosnącym podziałem pracy i postępująca atomizacja społeczeństwa, z jednej strony w coraz większym stopniu jesteśmy uzależnieni od współpracy z innymi członkami społeczeństwa, z drugiej zaś - stajemy się coraz bardziej anonimowi. Rośnie zakres wspólnych decyzji, które jednostki są zmuszone podejmować. W języku teorii gier jest to sytuacja odpowiadająca n-osobowemu dylematowi więźnia, rozgrywanemu przy udziale dużej liczby graczy. W tak zmieniającym się świecie coraz mniej prawdopodobne jest osiagnięcie rozwiązania optymalnego w sensie Pareto. Doktor Giza uważa, że eksperymenty teorii gier dowodzą skuteczności strategii „wet za wet” w kształtowaniu relacji społecznych, zgodnie ze wspomnianymi cechami: przyjazności, odwetowości, skłonności do przebaczania i spójności. Ponadto, jest zdania, że wykazują one pewne analogie z zasadami konstytuujacymi Euckena.

Profesor Janina Godłów-Legiędź, interpretując artykuł doktora Gizy, uznała za nieporozumienie czynienie analogii pomiędzy koncepcja Smitha i optimum Pareto. Idea spontanicznego porządku Smitha nie dotyczy - zdaniem Profesor - takich sytuacji, jak dylemat więźnia, lecz koordynacji wyższego rzędu - metakoordynacji, a poza tym intencja Smitha jest sprzeczna z ideą porozumienia graczy w dylemacie więźnia. Podobnie rynek nie służy temu, by grupy graczy osiagały porozumienie i realizowały swoje partykularne interesy. Profesor Janina Godłów-Legiędź spróbowała sama udzielić odpowiedzi na pytania stawiane przez dr, Gizę. Na pierwsze z nich „Czy rzeczywiście człowiek nie jest zdolny do świadomego kształtowania ładu gospodarczego?” odpowiedziała: Człowiek nieustannie próbuje kształtować ład gospodarczy, społeczny, polityczny, ale bardzo często wyniki tych wysiłków nie odpowiadają zamierzeniom, czyli jest tak, jak mówili szkoccy filozofowie moralni. Ostatnich przykładów dostarcza $m$. in.: zastosowanie nowoczesnych metod opanowania ryzyka na rynkach finansowych, polityka stabilizowania koniunktury, a także realizacja projektu europejskiej integracji walutowej. Odpowiadając na pytanie drugie „Czy dysponujące szerokim zakresem wolności jednostki zawsze będą zdolne do wygenerowania rozwiązania optymalnego z perspektywy całego społeczeństwa?", profesor uznała, że wolność w granicach prawa jest niezbywalnym atrybutem człowieka, a rozwiązanie optymalne z punktu widzenia całego społeczeństwa jest trudne do zdefiniowania. 
Profesor Piotr Pysz przejście od teorii gier do stanowionego ładu gospodarczego uznał za udane. Kluczem do tego jest dokonane przez antropologa i filozofa Maxa Schelera, ucznia Rudolfa Euckena, rozróżnienie pomiędzy „wolnością od czegoś“ oraz „wolnościa do czegoś“. W tym ujęciu, wolność nie może ograniczać się do uwalniania jednostek ludzkich od krępujacych ją ograniczeń i więzów. Wymaga ona uzupełnienia o wolność rozumiana pozytywnie jako wykorzystanie uzyskanej swobody wyboru i działania jednostek do realizacji celów służących zarówno im jak i większym grupom oraz społeczeństwu, czyli o odpowiedzialność za wolność.

Kolejny referent, profesor Maciej Miszewski z Uniwersytetu Ekonomicznego w Katowicach, zgodził się z profesor Godłów-Legiędź, iż zbiory poglądów przyjmują formę ideologii, a nauka wsparta podbudowa aksjologiczna daje lepsze wyniki. W swoim wystapieniu prowadził refleksję nad metodologicznymi i merytorycznymi powiązaniami pomiędzy ordoliberalizmem a neoinstytucjonalizmem w teorii ekonomii. Synteza obu tych nurtów w myśli ekonomicznej - zdaniem profesora Miszewskiego - wzbogaciłaby tę teorię. Omawiając różnice podejść pomiędzy nurtem neoklasycznym a neoinstytucjonalizmem, zauważył on, że rosnąca złożoność rzeczywistości gospodarczej stawia badaczy wobec alternatywy: redukować złożoność poprzez jej modelowanie i pomijanie rosnącej liczby uwarunkowań albo przyjąć postawę „pokory poznawczej”. Prelegent przeniósł ten dylemat na porównanie neoliberalizmu i ordoliberalizmu. Skrytykował ten pierwszy za coraz większe uproszczenia złożonej rzeczywistości, konieczne do utrzymania formalnej spójności wyrafinowanych modeli matematycznych. Z kolei, zdaniem profesora Miszewskiego, ordoliberalizm reprezentuje odmienne podejście metodologiczne, co zbliża go neoinstytucjonalizmu. Oba kierunki łączą też wspólne korzenie tkwiące w niemieckiej szkole historycznej, co jest widoczne w zbieżności myślenia Euckena, Veblena i Commonsa. Podejmując wątek holizmu, referent starał się wykazać, że obejmuje on pewne spektrum postaw badawczych i nie musi wcale kolidować z indywidualizmem metodologicznym. Współczesny neoinstytucjonalizm, podobnie jak ordoliberalizm, przyjmuje podejście umiarkowanego indywidualizmu metodologicznego. Podsumowując afiliacje pomiędzy neoinstytucjonalizmem a ordoliberalizmem, profesor Miszewski zwrócił uwagę na ich obecność w ekonomii heterodoksyjnej oraz możliwość syntezy w formie pewnej hybrydy metodologicznej. Neoinstytucjonalizm, połączony z dorobkiem szkoły fryburskiej, mógłby - według niego - stworzyć teorię, która ocali liberalne jądro ekonomii.

Profesor Anna Ząbkowicz w koreferacie uznała za trafne wyodrębnienie dwóch podejść badawczych: pokorę wobec możliwości poznawczych oraz redukcję złożoności i modelowanie. Zasugerowała konieczność dokładniejszego zdefiniowania nurtu neoinstytucjonalnego, jednak przestrzegła, że rzadko która teoria „czysto” przystaje do podziałów, wprowadzanych w celu usystematyzowania ekonomii. Holistyczna perspektywa poznawcza, wychodząca poza czynniki stricte ekonomiczne, pomogłaby lepiej zrozumieć zjawiska zachodzące w gospodarce, zgodnie z postulatem Myrdala, by wyjść poza „zamknięte modele”. Profesor Bogusław Fiedor z Uniwersytetu Ekonomicznego we Wrocławiu, próbując doprecyzować zakres rozważań, ulokował realizm poznawczy pomiędzy indywidualizmem metodologicznym a holizmem. Pytając o to, jak wyglądałby ordoliberalizm stosowany, uznał to za problem otwarty i wyraził pogląd, że nie da się osiagnąć tych idei przy pomocy rozbudowanego aparatu państwowego, lecz wymagałoby to rozbudowanych, ale neutralnych regulacji.

Kolejni prelegenci - doktor Anna Grabska z Uniwersytetu w Białymstoku i doktor Michał Moszyński z Uniwersytetu Mikołaja Kopernika w Toruniu omówili prace związane z projektem badawczym „Koncepcje stanowionego i spontanicznego ładu gospodarczego w procesie transformacji systemowej gospodarki Polski i byłej NRD”. Doktor Grabska przybliżyła podejście badawcze i wstępne wyniki w odniesieniu do transformacji gospodarki Polski, zaś doktor Moszyński - dla byłej NRD. Wspólnym elementem ich podejścia badawczego było sięgnięcie do dorobku nowej ekonomii instytucjonalnej i przyjęcie założeń, iż szukając przejawów obu rodzajów ładu gospodarczego, należy poszukiwać szeroko pojętych instytucji, przy czym elementy ładu stanowionego są tworzone przez państwo i jego organy, zaś spontanicznego pochodzą od podmiotów rynkowych. Prelegenci wskazali, iż wyzwanie opisania obu rodzajów 
ładu ma pionierski charakter i napotyka szereg problemów natury metodycznej, braku danych statystycznych i innych, jednak warto podejmować próby wykorzystania koncepcji ładu gospodarczego w analizach transformacji systemowej. Pierwsze rezultaty wydaja się potwierdzać wnioski wyprowadzone z refleksji teoretycznych, m.in. o: znacznym stopniu komplementarności obu rodzajów ładu, wysokim stopniu inercji norm i wartości jako „budulców instytucji” oraz pewnym oddziaływaniu zwrotnym elementów ładu stanowionego w reakcji na niepożądane tendencje w ładzie spontanicznym.

Drugi dzień konferencji poświęcono polityce gospodarczej w ramach ładu gospodarki rynkowej. Pierwsze dwa wystapienia objęły problem zrównoważonego i trwałego rozwoju wobec ordoliberalizmu i społecznej gospodarki rynkowej. Profesor Józefa Famielec z Uniwersytetu Ekonomicznego w Krakowie dokonała analizy teoretycznej kategorii rozwoju zrównoważonego w świetle ordoliberalnego ładu gospodarczego i oparła swe refleksje na głównej tezie, iż nie istnieje osobny ład ekologiczny, który można rozpatrywać w oderwaniu od innych elementów ładu gospodarczego. Zaproponowała, aby kategorię rozwoju zrównoważonego zintegrować z koncepcją ładu gospodarczego. Zrównoważenie w sensie Walrasowskim, ale nie tylko, można uznać za podstawowe, jeśli nie jedyne, kryterium stanu i zmian w gospodarce, regulowanej ustrojem gospodarczym. Ustrój oznacza ład, w którym przebiega proces gospodarowania, mający miarę i równowagę. Taki ład, inaczej ordo, to różnorodność połączona sensownie w całość, która odpowiada naturze człowieka i rzeczy. Należy poszukiwać takiego ustroju gospodarczego, który uwzględnia dwa łady - naturalny i stanowiony. W dalszej części wywodów profesor Famielec zestawiła Euckenowskie zasady konstytuujące ładu gospodarczego z koncepcją rozwoju zrównoważonego i doszła do wniosku, iż można nimi posłużyć się przy opisie kategorii rozwoju zrównoważonego.

Oceniając referat, profesor Godłów-Legiędź zgodziła się, że metodologiczne problemy ekonomii ekologicznej powinny być postrzegane i rozstrzygane jako problemy metodologiczne całej ekonomii. Ponadto, problemów racjonalnego wykorzystania zasobów naturalnych nie można oddzielać od ekonomii pracy i kapitału, podobnie jak nie można rozłączać problemów tzw. zrównoważonego rozwoju i ekonomii jako takiej. Profesor uznała, że odpowiedzialna jednostka jest podstawowym punktem odniesienia wzrostu zrównoważonego i fundamentem ładu społecznego. Doktryny indywidualistyczne ze społecznym ukorzenieniem jednostki, reprezentowane przez Smitha, a po nim Hayeka i ordoliberałów lepiej służą postępowi.

Profesor Bogusław Fiedor z Uniwersytetu Ekonomicznego we Wrocławiu podjał problem trwałego rozwoju widziany w perspektywie społecznej gospodarki rynkowej. Przyczynek do rozważań stanowiły uwagi na temat relacji pomiędzy trwałym rozwojem a rynkiem i państwem oraz przewaga prewentywnej polityki ochrony środowiska nad polityką reaktywna. W dalszej kolejności dokonał on interpretacji ekologicznej koncepcji społecznej gospodarki rynkowej na przykładzie Republiki Federalnej Niemiec. Pomiędzy koncepcjami trwałego rozwoju i społeczna gospodarką rynkową istnieją liczne związki i odniesienia. Jak zauważył prelegent: pozwalają one właśnie na sformułowanie pojęcia ekologicznej społecznej gospodarki rynkowej jako takiego modelu gospodarki rynkowej, w którym realizacja ordoliberalnie pojmowanych zasad wolności, własności prywatnej, sprawiedliwości społecznej i indywidualnej odpowiedzialności nie jest sprzeczna z zasadą wewnątrz- i międzypokoleniowej sprawiedliwości ekologicznej. Co więcej, „tworzenie „ekologicznego wymiaru” społecznej gospodarki rynkowej czy też nadawanie jej atrybutów trwałości, w rozumieniu koncepcji trwałego rozwoju, może i powinno również być postrzegane w kontekście ordoliberalnie rozumianej Ordnungspolitik, czyli polityki tworzenia ładu instytucjonalnego dla konkurencyjnej gospodarki rynkowej."

W komentarzu doktor Ewa Kulińska-Sałocha z Uniwersytetu Ekonomicznego w Poznaniu, ukazała, że nie sposób zapomnieć o silnej krytyce idei zrównoważonego rozwoju - określonej w literaturze nawet jako utopia, fikcja, czy wręcz oszustwo, z uwagi na jej iluzoryczne i irracjonalne założenia. $Z$ drugiej jednak strony - wskazała prelegentka - w kontekście porażek modelu społeczno-gospodarczego przełomu tysiącleci wybierane propozycje można traktować jako zaczyn nowego paradygmatu globalizującego się świata w konwencji ekospołecznej globalnej gospodarki rynkowej. 
Kolejny referat pod frapującym tytułem „Mały rząd, państwo minimum. A może raczej „bez rządu?" zaprezentował profesor Witold Kwaśnicki z Uniwersytetu Wrocławskiego. W niezwykle zajmujący sposób starał się uświadomić słuchaczom zmieniającą się rolę państwa w gospodarce w długim okresie, a przede wszystkim ewolucje percepcji rządu w oczach społeczeństwa. Ostrą krytykę działań państwa i rządu profesor Kwaśnicki oparł na zestawieniu oczekiwań i postulatów formułowanych wobec rządu z ich faktyczną realizacja. Przedstawił szereg danych statystycznych, ilustrujących rozrost sfery publicznej i zastanawiał się nad konsekwencjami tego stanu rzeczy dla postępu gospodarczego. Odnosząc się do tytułowego pytania, Autor przeanalizował pojęcie anarchii i jej rozumienie w ujęciu historycznym. Zauważył, że naczelną myśla, łącząca wszystkie ruchy anarchistyczne, jest przekonanie, że wszystko, co dotyczy człowieka, powinno być rozwiazywane przez oddolna aktywność jednostek lub ich grup. Przedstawił ich niechęć do istnienia jakiejkolwiek formy rządu centralnego. Podsumowując rozważania, profesor Kwaśnicki uznał, że: nie uzyska się zasadniczej poprawy rządzenia bez radykalnego ograniczenia wydatków publicznych i likwidacji deficytów budżetowych. Pierwotne powinno być właśnie drastyczne ograniczenie tych wydatków, a konsekwencją będzie poprawa efektywności rządzenia i ograniczenie marnotrawstwa.

Doktor Justyna Bokajło z Uniwersytetu Wrocławskiego porównała koncepcje ładu społeczno-gospodarczego w ujęciu A. Rüstowa, W. Röpke i A. Müllera-Armacka. Zakwalifikowała tych myślicieli do „nietypowych ordoliberałów”, którzy raczej pasuja do koncepcji Społecznej gospodarki rynkowej ${ }^{3}$. Prelegentka uznała, iż ich podejście „rozumiejącej socjologii” i „myślenia w kategoriach ładu" może nadać nową dynamikę koncepcji ordo. Wskazała na poglady Röpke, u którego ważną kategorią była osoba z własną wolą i świadomością. Rozpad więzi pomiędzy jednostką a wspólnotą to problem utrudniający urzeczywistnienie się ładu. Odejście od naturalnego porządku uaktywnia w społeczeństwie jego złe strony - animal spirits. Rüstow, podobnie jak Röpke, uważał, że koncentracja na wzroście nie doprowadzi wcale do wzrostu jakości życia. Armack - zdaniem doktor Bokałjo - skompilował wszystkie te poglądy. Wyszedł od ordo, uelastycznił tę koncepcję o poglądy Röpke i dodał Vitalpolitik Rüstowa. W poszukiwaniach „trzeciej drogi” postulował zrównoważenie i służebność ładu wobec człowieka. Reasumując, doktor Bokałjo uznała, że koncepcje Rüstowa, Röpke i Müllera-Armacka stanowią zapowiedź tego, co doświadczamy dziś w światowej gospodarce.

Kolejny prelegent, dziekan Wydziału Ekonomii i Zarządzania, profesor Henryk Wnorowski poświęcił swoje wystapienie przedsiębiorczości jako elementowi ładu gospodarczego. Opisał rolę przedsiębiorczości przypisywana jej przez przedstawicieli różnych nurtów w ekonomii i przedstawił wyniki swoich badań, które ukazały, że nie można oprzeć wzrostu tylko na instrumentach finansowych, lecz należy przede wszystkim dbać o dobre instytucje. Problem w tym, że dobre instytucje nie generują same popytu na siebie, a ich wprowadzenie narusza zawsze czyjeś interesy. Badania przeprowadzone przez profesora na grupie $22 \mathrm{kra}-$ jów Unii Europejskiej dowodza, że wszystkie kraje potrzebują rekomendacji dla polityki sprzyjającej rozwojowi przedsiębiorczości.

Prorektor Uniwersytetu w Białymstoku, profesor Robert Ciborowski, przygotował opracowanie pt.: „Schumpeterowska twórcza destrukcja a koncepcja rynkowego ładu gospodarczego". Zjawiska opisane przez Schumpetera korespondują z rosnącym zainteresowaniem innowacjami w procesie rozwoju gospodarczego. Prelegent stał na stanowisku, że przedstawienie procesu ewolucji systemów społeczno-ekonomicznych oraz kształtujących ją czynników, pozwala w bardziej analityczny sposób wyjaśnić proces formowania się i funkcjonowania ładu gospodarczego. Podsumowując rozważania, profesor Ciborowski stwierdził, że "gospodarki otwarte na przełomowe innowacje i przechodzące proces «twórczej destrukcji» mają większe możliwości dynamicznego rozwoju gospodarczego. Odbywa się to poprzez zmiany struktury produkcji i tworzenie nowego ładu gospodarczego bazującego na innowacyjnych przedsię-

3 Aby podkreślić całościowość koncepcji, będącej stylem gospodarowania społeczeństwa, Armack postulował, aby pisać „społeczna” wielką literą. Tę konwencję pielęgnują dziś np. środowiska niemieckiej socjaldemokracji. 
biorstwach. Schumpeterowski proces zmian w kapitalistycznej gospodarce jest raczej procesem skokowym a nie ciagłym. Wynika to z, wprowadzonych, nowatorskości rozwiazań technologicznych i, będącej ich konsekwencją, destrukcją funkcjonującego ładu gospodarczego."

Z uwagi na skrótowy charakter niniejszego opracowania przedstawiono jedynie główne tezy wystapień i naszkicowano przebieg obrad w okrojonej formie. Zaprezentowane referaty i koreferaty zostana zebrane w monografii naukowej, która zostanie przygotowana w 2013 r.

Konferencja, z uwagi na ciekawą formułę i kameralny charakter, stanowiła znakomite forum dyskusji i wymiany poglądów. Organizatorzy wyszli z założenia, iż specjalistyczne spotkanie okaże się bardziej efektywne niż rozległe tematycznie, przekrojowe konferencje i przyczyni się do zacieśnienia współpracy naukowej różnych ośrodków. Przyjazna atmosfera stworzona przez gospodarzy z Wyższej Szkoły Finansów i Zarządzania w Białymstoku oraz Uniwersytetu w Białymstoku przesądziła o niewątpliwym walorze obrad.

Uczestnicy wyrazili przekonanie, iż pogłębiona refleksja nad liberalizmem jest niezwykle potrzebna, zwłaszcza w sytuacji jego zmasowanej krytyki, która odbywa się bez rozróżnienia jego nurtów i wnikania w bogactwo ideowe. Szczególnie w okresie postkryzysowym podejmowanie tematyki relacji pomiędzy liberalnymi teoriami, dotyczącymi ładu gospodarczego a jego kształtowaniem przez politykę, wydaje się wskazane. 